\title{
Concentrations of retinol and carotenoids in Jersey milk during different seasons and possible application of the colour parameter as an indicator of milk carotenoid content
}

\author{
Nikolina Kelava Ugarković ${ }^{1}$, Tomislav Rusan ${ }^{2}$, Ivan Vnučec ${ }^{1}$, \\ Miljenko Konjačić ${ }^{1 *}$, Zvonimir Prpić ${ }^{1}$
}

\author{
'University of Zagreb, Faculty of Agriculture, Department of Animal Science and Technology, \\ Svetošimunska cesta 25, 10000 Zagreb, Croatia \\ ${ }^{2}$ Bjelovarska ulica 154, Donji Daruvar, 43500 Daruvar, Croatia \\ *Corresponding author: mkonjacic@agr.hr
}

\section{Abstract}

The aim of this study was to determine concentrations of retinol, $\beta$-carotene, lutein and zeaxanthin in Jersey milk during different seasons and their correlation with milk colour parameters. During a sixmonths period the Jersey cows $(n=77)$ were kept free-stall and fed with total mixed ratio (TMR; farm season), for the next three months the cows were kept for four hours on pasture and the rest of the day free-stall fed with TMR (transition season), and for the remaining three months they were kept predominantly on pasture (grazing season). A bulk milk samples $(200 \mathrm{~mL})$ were collected during the last week of each month in the period between May 2018 and April 2019. Retinol and carotenoids concentrations in cow milk were quantified using high performance liquid chromatography, while milk chemical composition was analysed by a MilkoScan FT 120 infra-red analyser. The season significantly $(P<0.05)$ affected chemical composition of milk, and the highest $(P<0.05)$ content of milk fat, protein and non-fat dry matter was found during the farm season. Retinol, $\beta$-carotene, lutein and zeaxanthin concentrations $(\mu \mathrm{g} / 100 \mathrm{~mL})$ were as follows: $2.56 \pm 0.29,4.15 \pm 0.27,4.43 \pm 0.40$ and $0.97 \pm 0.04$. Lutein and retinol concentrations in Jersey milk were affected $(P<0.05)$ by the season. The highest lutein concentration was found during the grazing season, while the farm season yielded the highest retinol concentration. Moderate and positive correlations $(P<0.05)$ were found between $\beta$-carotene and lutein concentrations and colour parameter $b^{*}$, resulting in a more intense yellow colour i.e. high values of colour parameter $b^{*}$. The obtained results suggest that milk colour could be used to estimate carotenoid concentrations in milk.

Key words: Jersey breed, milk chemical composition, carotenoids, diet, carotenoid content indicator 


\section{Introduction}

Milk plays a meaningful role in human nutrition and represents an important source of different essential nutrients such as lipids, proteins, minerals and vitamins, which are all required for normal growth and development (Ramalho et al., 2012). Vitamins, as complex organic micronutrients, are grouped into fat- and water-soluble and are present in milk in different forms (Plozza et al., 2012). The most abundant vitamin in milk is the fat-soluble vitamin $A$ that can be found in mixture of retinyl fatty acid esters and as free retinol. Thw amount of vitamin $A$ in milk can range from 10 to 100 $\mu \mathrm{g} / 100 \mathrm{~mL}$ milk (Haug et al., 2007). Generally, milk and milk products contribute $15-20 \%$ of vitamin A recommended dietary allowance (Hulshof et al., 2006; Ramalho et al., 2012). Regarding the human health, vitamin A has an important role in growth and development, cell differentiation, function of different tissues types, immune system function, embryo development, reproduction and postnatal growth (Beliveau, 2012). It is present in glycoprotein synthesis and growth hormone production (Weber and Grune, 2011). Aside from these important functions, one of the most known and predominant roles of vitamin $A$ is in human health vision (Beliveau, 2012; Ramalho et al., 2012).

Milk also contains provitamin A carotenoids. Carotenoids are fat-soluble, coloured pigments ranging from light yellow through orange to deep red. They are produced by different prokaryotes and eukaryotes (photosynthetic bacteria, some non-photosynthetic bacteria, yeasts, fungi, cyanobacteria, algae, higher plants) (Beliveau, 2012). Carotenoids are divided into xanthophylls (lutein and zeaxanthin) and carotenes (Vogdanou, 2014). The most prevalent carotenoid in cow milk is $\beta$-carotene, with amounts ranging from 3 to $50 \mu \mathrm{g} / 100 \mathrm{~mL}$, accounting for almost $90 \%$ of all carotenoids present in milk. These concentrations are followed by lutein and zeaxanthin (Hulshof et al., 2006; Nozière et al., 2006a; Morrissey and Hill, 2009). Animals cannot synthesize carotenoids de nova and diet is the only source of these nutrients. Regarding human health, carotenoids are important antioxidants and have preventative effects for various diseases like cardiovascular and eye disease, and certain cancers (Coultate, 2002). Using singlet oxygen and lipoperoxides $\beta$-carotene and retinol can prevent and limit milk fatty acid oxidation (Bergamo et al., 2003). As a result, carotenoids can improve oxidative stability of milk since they are characterized by antioxidative activity (Granelli et al., 1998).

Milk composition is affected by genetic factors, like breed and season, nutrition, stage of lactation, milking system as well as environmental factors (Ramalho et al., 2012). Numerous studies have evaluated effect of different environmental factors on milk vitamin concentrations (Havemose et al., 2004; Hulshof et al., 2006; Nozière et al., 2006b; Calderon et al., 2007; Ellis et al., 2007). The greatest influence on milk fat percentage and concentrations of fat-soluble vitamins and carotenoids have type of diets used in dairy cow nutrition. Grassbased diets, especially on pasture, result in higher milk $\beta$-carotene concentration than diets rich in concentrates or corn silage (Havemose et al., 2004; Nozière et al., 2006a). Type of forage is considered to be the main cause of seasonal variations in retinol and carotenoid concentrations of bulk milk. Higher milk retinol and carotenoid concentrations are found during summer months (grazing period) compared to period of conserved forages feeding (winter farm period) (Jensen et al., 1999). Thus, seasonal variations in dairy cows' rations can result in different concentrations of carotenoids in milk. Carotenoids are also able to influence the sensory characteristics of products, such as more intense yellow colour, but could also improve antioxidant properties of milk (Calderon et al., 2007; Kilcawley et al., 2018). Assessment of the presence and intensity of yellow colour in milk is considered as a potential biomarker, indicating feed management quality in dairy cows (Prache et al., 2002). Milk colour is related to $\beta$-carotene content in milk fat, but other components also contribute to milk colour (Solah et al., 2007). Agabriel et al. (2007) found that 30 to 43 percent of the variations in the intensity of the yellow milk colour indices can be explained by milk $\beta$-carotene content. Cows fed grass silage tend to produce milk with yellower fat and greater $\beta$-carotene content than milk produced by cows on a hay diet (Nozière et al., 2006b; Calderon et al., 2007). Dairy breeds which produce milk with a greater carotenoid and fat content, like Jerseys, produce milk that is more yellow than breeds such as Holstein-Friesians (Winkelman et al., 1999). 
Based on all of the previously mentioned facts and relations, the aims of this study were to determine the concentration of retinol, $\beta$-carotene, lutein and zeaxanthin in Jersey milk cow during different seasonal diets and to investigate their correlation with milk colour parameters.

\section{Materials and methods}

The experimental trial was conducted at a dairy farm ( $n=77$ Jersey dairy cows) situated in Lika-Senj County near the city Gospić, Croatia. The average milk lactation production during the analysed period was $4800 \pm 135 \mathrm{~L}$. Three different rations were included with varying nutritional contents, while milk sampling was done during three seasons: grazing, transition season and farm season.

A total mixed ration (TMR) presented in Table1 was used during the farm season, which lasted from October to March. The transition season occurred in April, August and September when the dairy cows were kept for half a day at pasture and half a day at the farm were TMR was available (Table 1). The grazing season on perennial pastures lasted from May to July, when dairy cows were kept

TABLE 1. Composition of the total mixed ration (TMR) during farm and transition season and supplemental ration during grazing season

\begin{tabular}{l|l|l|l}
\hline \multirow{2}{*}{ ration components } & \multicolumn{3}{|c}{ season } \\
\cline { 2 - 4 } & farm & transition & grazing \\
\cline { 2 - 4 } & \multicolumn{3}{|c}{ (kg/cow) } \\
\hline grass hay & 3.0 & 3.0 & - \\
\hline alfalfa haylage & 17.0 & 9.0 & - \\
\hline ground corn grain & 4.5 & 3.0 & 6.0 \\
\hline oat grain & 1.28 & 1.35 & 1.5 \\
\hline wheat meal & 1.0 & - & 2.0 \\
\hline wheat grain & 0.85 & 0.85 & 1.5 \\
\hline soybean cake & 1.0 & - & - \\
\hline sunflower cake & 1.0 & 0.6 & - \\
\hline molasses & 1.0 & 0.6 & - \\
\hline vitamins and minerals & 0.18 & 0.15 & 0.15 \\
\hline calcium carbonate & 0.07 & 0.07 & 0.07 \\
\hline
\end{tabular}

the whole day, between morning and evening milking, on pasture and supplemental feeding was applied as shown in Table 1.

Milk sampling was done in the period between May 2018 and April 2019, which included sampling at last week of each month during farm, transition and grazing season. Milk produced throughout the last week of each month was collected in a bulk tank and sampling of the accumulated milk occurred at the end of the week. For each sampling $(\mathrm{n}=12), 200 \mathrm{~mL}$ of bulk tank milk was collected in sterile tubes and stored at $-20^{\circ} \mathrm{C}$ until the analyses.

Concentrations of fat, protein, lactose and nonfat dry matter in milk samples were analysed by a MilkoScan FT 120 infra-red analyser (Foss Electric A/S, Hillerød, Denmark).

Carotenoids and retinol extraction from milk samples were done as described by Hulshof et al. (2006) and Nozière et al. (2006a). Milk samples were thawed and homogenized, and $2 \mathrm{~mL}$ of aliquot, in duplicate, was transferred to glass centrifugation tubes. To each tube $1 \mathrm{~mL}$ of distilled water, $2 \mathrm{~mL}$ of ethanol and $2 \mathrm{~mL}$ of hexane was added. Samples were vortexed (Velp Scientifica ZX3) and centrifuged (Eppendorf Centrifuge 5417R) for 10 minutes at $4000 \mathrm{~g}$. The upper layers were collected and transferred into $50 \mathrm{~mL}$ plastic tubes. The residue was re-extracted until the extract was colourless. To the organic phase, $2 \mathrm{~mL}$ of $15 \% \mathrm{NaOH}$ in ethanol was added and mixture was saponified overnight. The organic phase was then washed by adding $6 \mathrm{~mL}$ of water to each tube and then the mixture was vortexed and centrifuged for 5 minutes at $4000 \mathrm{rpm}$. After centrifugation, the water phase was removed and the procedure was repeated three times in order to wash away all remaining $\mathrm{NaOH}$. During the last wash, the hexane layer was collected in a flask and evaporated on a rotary evaporator (Laborata 400 efficient, Heidolph, Germany). The residue was dissolved in $300 \mu \mathrm{L}$ acetonitrile : methanol : methylene chloride solution (45:20:35, v/v/v).

Retinol and carotenoids were separated and quantified by HPLC (High Performance Liquid Chromatogryphy) and UV/Vis spectrophotometry. A reversed phase column Vydac 201TP54 (5 $\mu \mathrm{m}$; 4.6 x 150 mm; Grace Davison Discovery Sciences, USA) was used in order to determine carotenoids contetn

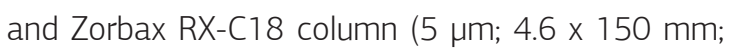


Agilent Technologies, USA) was used for retinol determination, containing silica polymerically modified with C18. A Supelguard Discovery $(5 \mu \mathrm{m} ; 4 \times 20$ mm; Supelco, USA) C 18 column was also used as a guard for other colums.

The HPLC system SpectraSystem (Thermo Separation Products, Inc., USA) was equipped with a quarter gradient pump (model P4000), a solvent degasser (model SCM 1000), a temperature-controlled auto sampler (model AS3000), pump heater, UV-visible forward optical scanning detector (model UV2000) and a fluorescent detector (model FL3000). Data was collected and analysed using ChromQuest 5.0 software (Thermo Fisher Scientific, USA).

Separations were achieved using a mixture of acetonitrile : methanol : methylene chloride (75:20:5, v/v/v), $0.05 \%$ triethylamine (TEA) and 0.1 $\%$ BHT. The column flow rate was $0.7 \mathrm{~mL} / \mathrm{min}$ at room temperature. Injection sample volume was 30 $\mu \mathrm{L}$. Separations were monitored at $325 \mathrm{~nm}(0-5.75$ min) and at $450 \mathrm{~nm}$ (5.75-20 min) for the identification and quantification of retinol and carotenoids, respectively (Hulshof et al., 1997).

Retinol and $\beta$-carotene standards were obtained from Sigma Chemical Company, prepared in ethanol and the concentrations of the standards were measured in a spectrophotometer using the extinction coefficients. Final working standards were prepared in methanol/THF (3:1 v/v) after stock standards were appropriately diluted. Individual standards were injected into the HPLC system and retention time was detected in order to determine each individual analysed element. Using different aliquots of standard solutions, five standards with different concentrations for five points of a calibration line were prepared. Combined retinol and $\beta$-carotene aliquots were evaporated on rotary evaporator and dissolved in $1 \mathrm{~mL}$ acetonitrile: methanol : methylene chloride solution (45:20:35, v/v/v). Carotenoid contents were presented as micrograms per 100 $\mathrm{mL}$ of milk.

Milk colour was determined as described by McDermott et al. (2015). Milk colour was measured using a Chroma Meter CR400 (Konica Minolta, Nieuwegein, the Netherlands) with a closed cone, set on the $L^{*} a^{*} b^{*}$ system. The Chroma meter was calibrated on a white tile priori measurement. Ten $\mathrm{mL}$ of each milk sample was added to a cuvette and expressed using the CIE- $L^{*} a^{*} b^{*}$ uniform colour space (CIELAB, 1976). The CIE-L*a* b* uniform colour space $L^{*}$ represents lightness (on a scale from 0 to 100 , where $0=$ black and $100=$ white), redness index $a^{*}$ (where $-a^{*}$ has a green colour and $+a^{*}$ has a red colour), and yellowness index $b^{*}$ (where $-b^{*}$ has a blue colour and $+b^{*}$ has a yellow colour).

Data was analysed in SAS V9.4 (SAS Inst. Inc., 2013), using GLM procedure and Tukey test. PROC CORR was used to calculate Spearman correlation coefficients. Significance level was set at $\mathrm{P}<0.05$.

\section{Results and discussion}

The chemical compositions of milk samples are shown in Table 1. Results obtained in this study, regarding the Jersey milk chemical composition, were improved compared to results reported by Holstein and Simmental dairy cows included in a milking control in Croatia (Ministry of Agriculture, 2019). This is in line with the results reported by Capper and Cady (2012), who claimed the Jersey breed is known to produce milk with higher milk fat and protein contents than other dairy breeds, especially

TABLE 2. Chemical composition (\%) of Jersey milk during different seasons

\begin{tabular}{l|l|l|l|l}
\hline Season of sampling & Milk fat & Protein & Lactose & Non-fat dry matter \\
\hline Grazing & $5.19 \pm 0.21^{\mathrm{a}}$ & $3.56 \pm 0.08^{\mathrm{a}}$ & $4.41 \pm 0.06$ & $9.05 \pm 0.08^{\mathrm{a}}$ \\
\hline Transition & $5.69 \pm 0.21^{\mathrm{ab}}$ & $3.91 \pm 0.08^{\mathrm{b}}$ & $4.37 \pm 0.06$ & $9.40 \pm 0.08^{\mathrm{b}}$ \\
\hline Farm & $6.10 \pm 0.16^{\mathrm{b}}$ & $4.12 \pm 0.06^{\mathrm{b}}$ & $4.28 \pm 0.04$ & $9.59 \pm 0.06^{\mathrm{b}}$ \\
\hline Mean & $5.74 \pm 0.16$ & $3.92 \pm 0.28$ & $4.34 \pm 0.11$ & $9.39 \pm 0.26$ \\
\hline
\end{tabular}

a,b $\mathrm{LSMEAN} \pm \mathrm{SE}$; values within column marked with different letter differ significantly $(\mathrm{P}<0.05)$ 
Holstein. Larsen et al. (2012) reported that milk fat and protein content in Danish Jersey milk is similar to the results obtained in this study.

The season had a significant $(P<0.05)$ effect on milk fat, protein and non-fat dry matter content, while milk lactose content was consistent throughout the seasons (Table 1). During the grazing season the lowest $(P<0.05)$ content of milk fat, milk protein and non-fat dry matter was found, compared to other seasons. The similar effect of season on milk chemical composition was reported by Yasmin et al. (2012) and Bernabucci et al. (2015).

The season significantly $(P<0.05)$ affected lutein and retinol concentration in analysed milk samples (Figure 1). The highest $(P<0.05)$ concentration of lutein was found during the grazing season, followed by transition and then farm-feeding season. The same pattern of seasonal changes was found for $\beta$-carotene concentration ( $P>0.05)$. On the other hand, the highest $(P<0.05)$ retinol concentrations were found during the farm season, followed by the grazing and then transition season. These results contradict those previously reported (Jensen et al., 1999). However, for this study, the predominant voluminous forage used during the farm season in the dairy cow ration was alfalfa haylage which presumably resulted in the higher retinol content during this season. A similar seasonal effect on milk carotenoid concentration was reported by Marino et al. (2012). Calderon et al. (2007) reported lower concentrations of $\beta$-carotene and lutein, but higher concentrations of retinol in Montbeliarde milk when compared to the results obtained in this study. Similarly, lower carotenoid concentrations in milk of Brown Swiss and Holstein were reported by Marino et al. (2012) and Johansson et al. (2014). However, Johansson et al. (2014) reported higher retinol concentration than found in the present study. Higher concentration of $\beta$-carotene, but lower retinol and lutein concentrations were reported by Hulshof et al. (2006) in Holstein milk. The dietary and nondietary effects on carotenoid concentrations in milk of dairy cows has been previously reported by Nozière et al. (2006a). The type of forage and ration composition are the main dietary factors contributing to variations in milk $\beta$-carotene concentrations (Calderon et al., 2007). Due to that, results of $\beta$-carotene concentration presented in different studies may differ notably even
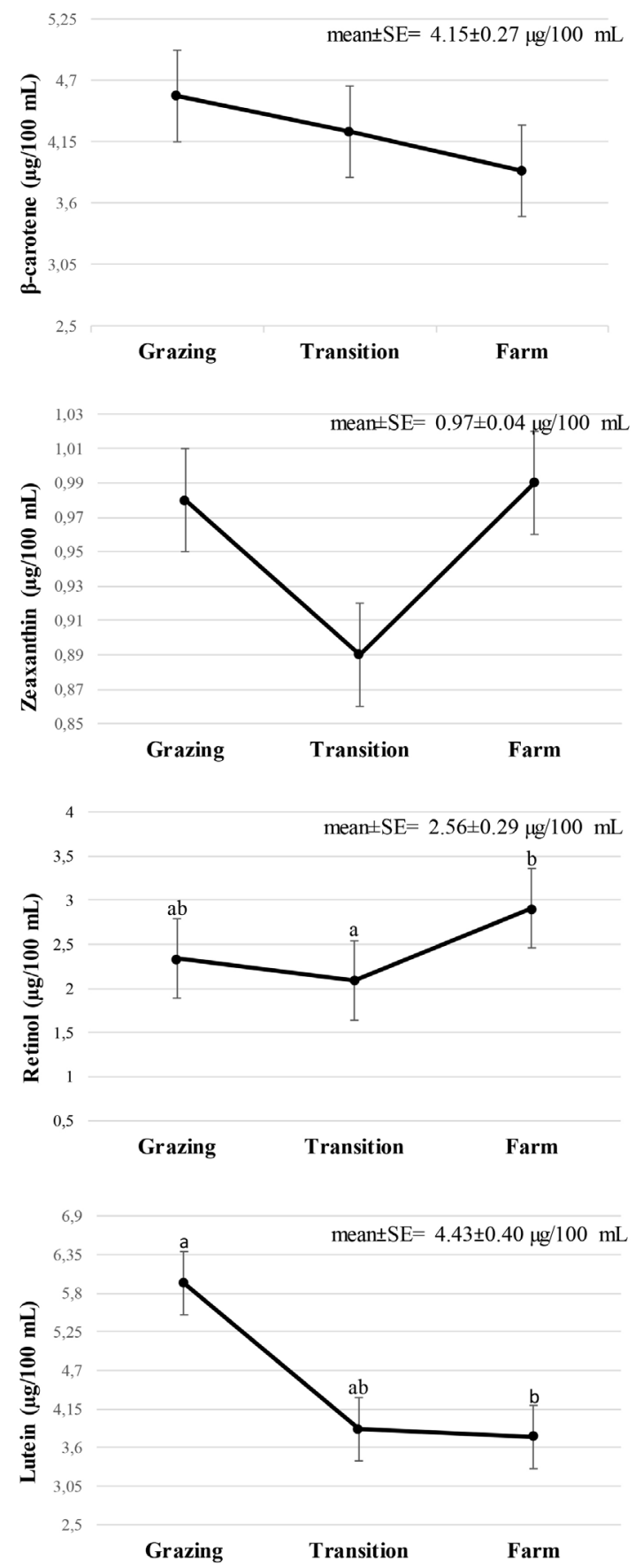

a,b $L S M E A N \pm S E$ marked with different letter differ significantly $(P<0.05)$

FIGURE 1. Concentrations $(\mu \mathrm{g} / 100 \mathrm{~mL})$ of $\beta$-carotene, lutein, zeaxanthin and retinol in Jersey milk during different seasons

when comparing the same dairy breed. The comparison of the results from previous studies with the present results is very often complicated due to the fact that different units are used to quantify 
TABLE 3. Colour parameters of Jersey milk during different seasons

\begin{tabular}{l|l|l|l}
\hline $\begin{array}{l}\text { Season of } \\
\text { sampling }\end{array}$ & $\mathrm{L}^{*}$ & $\mathbf{a}^{*}$ & $\mathbf{b}^{*}$ \\
\hline Grazing & $93.67 \pm 1.83$ & $-5.54 \pm 0.27^{\mathrm{a}}$ & $21.39 \pm 1.36^{\mathrm{a}}$ \\
\hline Transition & $95.10 \pm 1.83$ & $-4.99 \pm 0.27^{\mathrm{ab}}$ & $16.97 \pm 1.36^{\mathrm{ab}}$ \\
\hline Farm & $95.28 \pm 1.29$ & $-4.59 \pm 0.19^{\mathrm{b}}$ & $16.71 \pm 0.95^{\mathrm{b}}$ \\
\hline Mean & $94.83 \pm 0-85$ & $-4.93 \pm 0.17$ & $17.94 \pm 0.86$ \\
\hline
\end{tabular}

a,b $L S M E A N \pm S E$ values within column marked with different letter differ significantly $(P<0.05)$

concentration of different carotenoids and vitamins ( $\mu \mathrm{g} / \mathrm{g}$ milk fat, $\mu \mathrm{g} / \mathrm{mL}, \mu \mathrm{g} / 100 \mathrm{~mL}, \mu \mathrm{g} / 100 \mathrm{~g}$ ).

In Table 2 CIE L*a*b* colour parameters of Jersey milk are shown. Lower values of $L^{*}$ and $b^{*}$ colour parameters were reported by Vogdanou (2014) in Jersey milk fed with grass silage harvested during different seasons, while values of $a^{*}$ colour parameter were similar. Similarly, McDermott et al. (2016) reported lower $L^{*}$ and $b^{*}$ parameters in Jersey milk kept in grazing system, whereas the value of parameter $a^{*}$ was similar. It is more commonly found that Jersey cows produce milk with higher carotenoid and fat contents, and consequently their milk has a more intense yellow colour than milk of some other dairy breeds (Winkelman et al., 1999). Values of colour parameter $b^{*}$ in Holstein milk from grazing system, reported by McDermott et al. (2016), were lower compared to results obtained in this study. However, in the present study similar values of colour parameters $b^{*}$ were found to those reported in Holstein milk during seasonal feeding regimes (Solah et al., 2007). More precisely, differences in milk colour are mainly affected by dietary factors and milk colour can be altered greatly depending on dairy cows' ration composition (Agabriel et al., 2007). A more intense $(P<0.05)$ white colour $\left(L^{*}\right)$ was found in milk produced during the transition and farm-feeding seasons compared to grazing season results (Table 3 ). Negative values of parameter $\mathrm{a}^{*}$ were found during all three seasons, with the grazing season being higher $(P<0.05)$ in comparison to the farming season. More intense yellow colour (i.e. higher parameter $b^{*}$ ) was found during the grazing season compared to the farm-feeding season $(P<0.05)$. These results are most probably due to higher concentration of carotenoids in the fresh voluminous forage that were transferred into milk throughout the grazing season (Nozière et al., 2006a).

Correlation coefficients between milk carotenoid concentration and milk colour parameters in Jersey milk are shown in Table 3. Moderate positive correlations $(P<0.05 ; P<0.001)$ were found between $\beta$-carotene and lutein concentration and milk colour parameter $b^{*}$. On the other hand, moderate negative correlations $(P>0.05)$ of $\beta$-carotene and lutein concentration with milk colour parameter $\mathrm{a}^{*}$ were found. This was expected as parameter $a^{*}$ covers the colour spectra between red and green, and all milk carotenoids contribute to milk's yellowness (i.e. value of parameter $\left.b^{*}\right)$. These results correspond to the results reported by Calderon et al. (2006) and Kilcawley et al. (2018). Zeaxanthin, as a minor milk carotenoid, showed low correlation coefficients $(\mathrm{P}>0.05)$ with the analysed milk colour parameters

TABLE 4. Correlation coefficients between carotenoid concentrations and colour parameters of Jersey milk

\begin{tabular}{l|l|l|l|l|l|l|l}
\hline & $L^{*}$ & $a^{*}$ & $b^{*}$ & $\beta$-carotene & Lutein & Zeaxanthin & Retinol \\
\hline$L^{*}$ & - & $0.730^{* *}$ & -0.118 & -0.176 & 0.289 & 0.296 & -0.148 \\
\hline$a^{*}$ & & - & -0.491 & -0.476 & -0.362 & -0.188 & -0.458 \\
\hline$b^{*}$ & & & - & $0.566^{*}$ & $0.664^{* *}$ & 0.032 & 0.442 \\
\hline$\beta$-carotene & & & & - & $0.541^{*}$ & 0.144 & -0.458 \\
\hline Lutein & & & & - & 0.412 & -0.231 \\
\hline Zeaxanthin & & & & & & - & 0.183 \\
\hline Retinol & & & & & & - & - \\
\hline
\end{tabular}

${ }^{*} \mathrm{P}<0.05,{ }^{* *} \mathrm{P}<0.001$ 
(Table 3). The yellow colour ( $b^{*}$ ) of bovine milk is closely related to the level of $\beta$-carotene and fat content, and it was found that the $\beta$-carotene concentration explains about $40 \%$ of variability in milk colour (Nozière et al., 2006b). As a result, greater milk fat and $\beta$-carotene content results in an increase of milk colour parameter $b^{*}$, resulting in more yellow colour. It has been suggested that feeding strategies can be used to alter carotenoid content in milk and consequently in dairy products (Nozière et al., 2006a).

\section{Conclusion}

The present study confirmed the presence of high milk fat and protein content in Jersey milk, and it was found that these contents are affected by seasonal changes in nutrition. Namely, during the farm season higher concentrations of both, fat and protein, were found. Seasonal changes in the types of forage and ration compositions impacted the concentrations of lutein and retinol in Jersey milk. Lutein concentration was higher during a grass-based diet, while retinol concentration was higher during the farm season where alfalfa haylage feedings were given. Regarding previous studies, a more intense yellow colour (i.e. high values of milk colour parameter $b^{*}$ ) was found in Jersey milk, especially during the grazing season. Moderate and positive correlations were found between $\beta$-carotene and lutein concentration and colour parameter $b^{*}$, suggesting that milk colour can be used to estimate carotenoid concentrations in milk.

\section{Acknowledgment}

Authors would like to thank EKO VEDRINE d.o.o. and Mr. Dominik Zeko for collaboration and organisational support during the research.

\section{Koncentracija retinola i karotenoida u mlijeku krava Jersey pasmine tijekom različitih sezona te mogućnost primjene parametra boje kao pokazatelja sadržaja karotenoida u mlijeku}

\section{Sažetak}

Cilj ovog rad bio je utvrditi utjecaj sezone na koncentraciju retinola, $\beta$-karotena, luteina i zeaksantina u mlijeku Jersey krava, te njihovu povezanost s pokazateljima boje mlijeka. Krave $(n=77)$ su tijekom šestomjesečnog razdoblja držane u staji i hranjene kompletno miješanim obrokom (TMR; farmska sezona), tijekom tri mjeseca boravile se četiri sata na pašnjaku i ostatak dana u staji te hranjene TMR-om (prijelazna sezona), dok su tri mjeseca cijeli dan držane na paši uz dohranu koncentratom (pašna sezona). U razdoblju od svibnja 2018. do travnja 2019. godine tijekom zadnjeg tjedna svakog mjeseca prikupljani su skupni uzorci mlijeka (200 mL). Koncentracije retinola i karotenoida u mlijeku su kvantificirane primjenom tekućinske kromatografije visoke djelotvornosti, dok je kemijski sastav mlijeka određen primjenom uređaja MilkoScan FT 120. Sezona je imala značajan $(P<0,05)$ utjecaj na kemijski sastav mlijeka te je najveći $(P<0,05)$ prosječni sadržaj mliječne masti, bjelančevina i bezmasne suhe tvari u mlijeku utvrđen tijekom farmske sezone Prosječne koncentracije ( $\mu \mathrm{g} / 100 \mathrm{~mL}$ ) retinola, $\beta$-karotena, luteina i zeaksantina u mlijeku su iznosile: $2,56 \pm 0,29 ; 4,15 \pm 0,27 ; 4,43 \pm 0,40 ;$ i 0,97 $\pm 0,04$. Utvrđen je značajan $(P<0,05)$ utjecaj sezone na koncentracije luteina i retinola pri čemu je najveća koncentracija luteina utvrđena je tijekom pašne sezone, dok je najveća koncentracija retinola utvrđena u mlijeku tijekom farmske sezone. Umjerene i pozitivne korelacije $(\mathrm{P}<0.05)$ utvrđene su između koncentracije $\beta$-karotena, odnosno koncentracije luteina i b* parametra boje mlijeka što se očituje u žućoj boji mlijeka, odnosno većoj vrijednosti parametra boje b*. Stoga, boja mlijeka može poslužiti u procjeni koncentracije karotena u mlijeku.

\section{Ključne riječi: kemijski sastav mlijeka, karotenoidi mlijeka, Jersey pasmina, hranidba}


1. Agabriel, C., Cornu, A., Journal, C., Sibra, C., Grolier, P., Martin, B. (2007): Tanker milk variability according to farm feeding practices: vitamins $A$ and $E$, carotenoids, color, and terpenoids. Journal of Dairy Science 90, 48844896. https://doi.org/10.3168/jds.2007-0171

2. Beliveau, A.R. (2012): Variations in carotenoids and retinol in milk and cheese from Jersey cows at an organic dairy compared to a conventional dairy over a pasture season. Master's Theses and Capstones. University of New Hampshire, Durham, USA.

3. Bergamo, P., Fedele, E., lannibelli, L., Marzillo, G. (2003): Fat-soluble vitamin contents and fatty acid composition in organic and conventional Italian dairy products. Food Chemistry 82, 625-631. https://doi.org/10.1016/S0308-8146(03)00036-0

4. Bernabucci, U., Basiricò, L., Morera, P., Dipasquale, D., Vitali, A., Piccioli Cappelli, F., Calamari, L. (2015): Effect of summer season on milk protein fractions in Holstein cows. Journal of Dairy Science, 1815-1827. https://doi.org/10.3168/jds.2014-8788

5. Calderon, F., Chauveau-Duriot, B., Martin, B., Graulet, B., Doreau, M., Noziere, P. (2007): Variations in carotenoids, vitamins $\mathrm{A}$ and $\mathrm{E}$, and color in cow's plasma and milk during late pregnancy and the first three months of lactation. Journal of Dairy Science 90, 2335-2346. https://doi.org/10.3168/jds.2006-630

6. Capper, J.L., Cady, R.A. (2012): A comparison of the environmental impact of Jersey compared with Holstein milk for cheese production. Journal of Dairy Science 95 (1), 165-176. https://doi.org/10.3168/jds.2011-4360

7. CIELAB (1976): CIELAB Colour System. Commission International de l'Eclairage, Paris, France.

8. Coultate, T.P. (2002): Food. The Chemistry of its Components (fourth edition). The Royal Society of Chemistry, Cambridge, UK.

9. Ellis, K.A., Monteiro, A., Innocent, G.T., Grove-White, D., Cripps, P., McLean, W.G., Howard, C.H., Mihm, M. (2007): Investigation of the vitamins $A$ and $E$ and $\beta$-carotene content in milk from UK organic and conventional dairy farms. Journal of Dairy Research 74, 484-491. https://doi.org/10.1017/S0022029907002816

10. Granelli, K., Barrefors, P., Bjoerck, L., Appelqvist, L.A. (1998): Further studies on lipid composition of bovine milk in relation to spontaneous oxidised flavour. Journal of the Science of Food and Agriculture 77 (2), 161-171. https://doi.org/10.1002/(SICI)10970010(199806)77:2\%3C161::AID-JSFA16\%3E3.0.CO;2-H

11. Haug, A., Høstmark, A.T., Harstad, O.M. (2007): Bovine milk in human nutrition - A review. Lipids in Health and Disease 6, 25-40.

12. Havemose, M.S., Weisbjerg, M.R., Bredie, W.L.P., Nielsen, J.H. (2004): Influence of feeding different types of roughage on the oxidative stability of milk. International Dairy Journal 14, 563-570. https://doi.org/10.1016/j.idairyj.2003.11.005
13. Hulshof, P.J.M., Xu, C., van de Bovenkamp, P., West M.E and C.E. (1997): Application of a validated method for the determination of provitamin A carotenoids in Indonesian foods of different maturity and origin. Journal of Agricultural and Food Chemistry, 45, 1174-1179. https://doi.org/10.1021/jf9603137

14. Hulshof, P.J.M., van Roekel-Jansen, T., van de Bovenkamp, P., West, C.E. (2006): Variation in retinol and carotenoid content of milk and milk products in The Netherlands. Journal of Food Composition and Analysis 19 (1), 67-75. https://doi.org/10.1016/j.jfca.2005.04.005

15. Jensen, S.K., Johannsen, A.K.B., Hermansen, J.E. (1999): Quantitative secretion and maximal secretion capacity of retinol, beta-carotene and alpha-tocopherol into cow's milk. Journal of Dairy Research 66, 511-522. https://doi.org/10.1017/S0022029999003805

16. Johansson, B., Persson, Waller, K., Jensen, S.K., Lindqvist, H., Nadeau, E. (2014): Status of vitamins E and A and $\beta$-carotene and health in organic dairy cows fed a diet without synthetic vitamins. Journal of Dairy Science 97 (3), 1682-1692.

https://doi.org/10.3168/jds.2013-7388

17. Kilcawley, K.N., Faulkner, H., Clarke, H.J., O’Sullivan, M.G., Kerry, J.P. (2018): Factors influencing the flavour of bovine milk and cheese from grass based versus non-grass based milk production systems. Foods 7 (3), E37. https://doi.org/10.3390/foods7030037

18. Larsen, M.K., Hymøller, L., Brask-Pedersen, D.B., Weisbjerg, M.R. (2012): Milk fatty acid composition and production performance of Danish Holstein and Danish Jersey cows fed different amounts of linseed and rapeseed. Journal of Dairy Science 95 (7), 3569-357. https://doi.org/10.3168/jds.2011-5163

19. Marino, V.M., Schadt, I., La Terra, S., Manenti, M., Caccamo, M., Licitra, G., Carpino, S. (2012): Influence of season and pasture feeding on the content of a-tocopherol and $\beta$-carotene in milk from Holstein, Brown Swiss and Modicana cows in Sicily. Dairy Science and Technology 92 (5), 501-513. https://doi.org/10.1007/s13594-012-0069-2

20. McDermoot, A., Visentin, G., McParland, S., Berry, D.P., Fenelon, M.A., De Marchi, M. (2016): Effectiveness of midinfrared spectroscopy to predict the color of bovine milk and the relationship between milk color and traditional milk quality traits. Journal of Dairy Science 99 (5), 3267 3273. https://doi.org/10.3168/jds.2015-10424

21. Ministry of Agriculture (2019): Annual report for cattle breeding in Republic of Croatia. Ministry of Agriculture, Zagreb. Available at: https://hpa.mps.hr/wp-content/ uploads/2019/05/gi-2018-govedarstvo.pdf [Accessed 12 December 2019].

22. Morrissey, P., Hill, T. (2009): Fat-soluble vitamins and vitamin C in milk and milk products. In: McSweeney, P., Fox, P. (eds.) Advanced Dairy Chemistry. Springer, New York, pp. 527-572. https://doi.org/10.1007/978-0-387-84865-5_12 
23. Nozière, P., Graulet, B., Lucas, A., Martin, B., Grolier, P., Doreau, M. (2006a): Carotenoids for ruminants from forages to dairy products. Animal Feed Science and Technology 131, 418-450. https://doi.org/10.1016/j.anifeedsci.2006.06.018

24. Nozière, P, Grolier, P, Durand, D, Ferlay, A, Pradel, P., Martin, B. (2006b): Variations in carotenoids, fat-soluble micronutrients, and color in cows'plasma and milk following changes in forage and feeding level. Journal of Dairy Science 89, 2634-48. https://doi.org/10.3390/foods7030037

25. Palladino, R.A., Buckley, F., Prendiville, R., Murphy, J.J., Callan, J., Kenny, D.A. (2010): A comparison between Holstein-Friesian and Jersey dairy cows and their F1 hybrid on milk fatty acid composition under grazing conditions. Journal of Dairy Science 93 (5), 2176-2184. https://doi.org/10.3168/jds.2009-2453

26. Plozza, T., Craige Trenerry, V., Caridi, D. (2012): The simultaneous determination of vitamins $\mathrm{A}, \mathrm{E}$ and b-carotene in bovine milk by high performance liquid chromatography - ion trap mass spectrometry (HPLC$\left.M^{n}\right)$. Food Chemistry 134, 559-563.

https://doi.org/10.1016/j.foodchem.2012.02.121

27. Prache, S., Priolo, A., Jailler, H., Dubroeucq, H., Micol, D., Martin, B. (2002): Traceability of grass-feeding by quantifying the signature of carotenoid pigments in herbivores meat, milk and cheese. In: Proceedings of the $19^{\text {th }}$ General Meeting of the European Grassland Federation, La Rochelle, France, pp. 592-593.
28. Ramalho, H.M.M., Santos, J., Casal, S., Alves, M.R., Oliveira, M.B.P.P. (2012): Fat-soluble vitamin (A, D, E and $\beta$-carotene) contents from a Portuguese autochthonous cow breed - Minhota. Journal of Dairy Science 95, 5476-5484. https://doi.org/10.3168/jds.2010-3975

29. SAS Inst. Inc. (2013): SAS/STAT ${ }^{\circledR} 9.2$ User's Guide, Cary, NC: SAS Institute Inc.

30. Solah, V.A., Staines, V., Honda, S., Limley, H.A. (2007): Measurement of milk color and composition: Effect of dietary intervention on Western Australian HolsteinFriesian cow's milk quality. Journal of Food Science 72 (8), S560-S566. https://doi.org/10.1111/j.1750-3841.2007.00491.x

31. Vogdanou, S. (2014): Milk composition affected by feeding Jersey cows grass silage of different harvest times with or without rapeseed supplementation. MSc Thesis. Aarhus University \& Wageningen University.

32. Weber, D., Grune, G. (2011): The contribution of betacarotene to vitamin A supply of humans. Molecular Nutrition and Food Research 55, 1-8. https://doi.org/10.1002/mnfr.201100230

33. Winkelman, A.M., Johnson, D.L., MacGibbon, A.K.H. (1999): Estimation of heritabilities and correlations associated with milk color traits. Journal of Dairy Science 82, 215-24. https://doi.org/10.3168/jds.S0022-0302(99)75226-4

34. Yasmin, A., Huma, N., Butt, M.S., Zahoor, T., Yasin, M. (2012): Seasonal variation in milk vitamin contents available for processing in Punjab, Pakistan. Journal of the Saudi Society of Agricultural Sciences 11 (2), 99-105. https://doi.org/10.1016/j.jssas.2012.01.002 